Savunma Bilimleri Dergisi

The Journal of Defense Sciences

Mayıs / May 2021, Say1/Issue 39.

ISSN (Bas1l1) : 1303-6831 ISSN (Online): 2148-1776

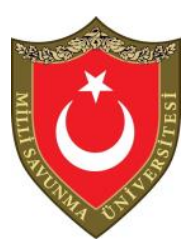

\title{
Girişimci Liderlik Ölçeği’nin Geçerlik ve Güvenirlik Çalışması ve Girişimci Liderliğin Bireysel Performansa Etkisi* $^{*}$
}

\author{
Mustafa BEKMEZCI ${ }^{* *}$, Muhammet SAYGIN ${ }^{* * * *}$ ve Kenan ORÇANLI ${ }^{* * * * *}$
}

$\ddot{O} z$

Bu çalışmada, ilk olarak Renko vd. (2015) tarafindan geliştirilen "Girişimci Liderlik Ölçeği” nin Türkçeye uyarlanması amacıyla tercümesi, geçerlik ve güvenirlik çalışması yapılmış; müteakiben girişimci liderlik davranışının, çalışanların bireysel performansını nasıl etkilediği araştırılmıştır. Araşstırma evrenini Mersin'de faaliyette bulunan lojistik firma çalışanları oluşturmakta olup, çalışmanın anakütlesi 3000 kişi ve örneklemi ise 453 kişidir. Çalışmada kullanılan veriler, iki adet ölçek ile kolayda örnekleme yöntemi ile toplanmıştır. Çalışmada ölçeklerin geçerliklerin ve güvenirliklerin sağlanmasında açıklayıcı ve doğrulayıcı faktör analizi, değişkenler arasındaki ilişkilerin belirlenmesinde korelasyon analizi ve kurulan modelin yapısal olarak incelenmesinde yapısal eşitlik modeli yöntemleri kullanılmıştır. Çalışmada yapılan analizler, SPSS ve AMOS paket programları ile yapılmıştır. Çalışmanın sonunda; Girişimci Liderlik Ölçeği'nin tek boyutlu bir ölçek olduğu, belirlenen bir alt boyutun modelin toplam varyansın \%65,807 oranında

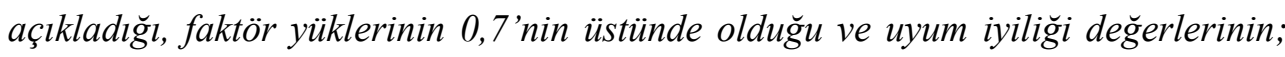
$\chi^{2} / d f:$ 2,758, GFI: 0,973, CFI: 0,987, RMSEA: 0,062 olduğu tespit edilmiştir. Ayrica değişkenler arasındaki ilişsinin anlamlı ve orta düzeyde ayn yönlü $(r=0,451, p<0,01)$

\footnotetext{
* Bu araştırma, 03-05 Ekim 2019 tarihinde gerçekleştirilen 2. Liderlik Akademisinde sözlü olarak sunulan bildirinin gelen öneri ve eleştiriler doğrultusunda geliştirilmiş halidir.

** Prof.Dr., Toros Üniversitesi, İ̇SBF, İşletme Bölümü, mustafa.bekmezci@toros.edu.tr, ORCID: 0000-0002-1206-690X

*** Doç.Dr., Mersin Üniversitesi Silifke MYO, msaygin@mersin.edu.tr, ORCID: 00000002-7871-0235

**** Dr.Öğr.Üyesi, Toros Üniversitesi, İ̇SBF, İşletme Bölümü, kenan.orcanli@ toros.edu.tr, ORCID: 0000-0001-5716-4004

Geliş Tarihi/Received : 05.06.2020

Kabul Tarihi/Accepted : 04.11.2020

Araştırma Makalesi/Research Article DOI: 10.17134/khosbd.913791
} 
olduğu ve giriş̧imci liderliğin bireysel performansı anlamlı bir şekilde etkilediği sonucuna varllmıştır.

Anahtar Kelimeler: Girişimci Liderlik, Performans, Geçerlik, Güvenirlik.

\title{
Validity and Reliability of Entrepreneurial Leadership Scale and the Effect of Entrepreneurial Leadership on Individual Performance
}

\begin{abstract}
In this study, the validity and reliability study of the "Entrepreneurial Leadership scale" developed by Renko et al. (2015) to adapt to Turkish, was conducted and then it was investigated how entrepreneurial leadership behavior affects the individual performance of employees. The research participants consist of employees of logistics companies operating in Mersin and the total number of participants is 3000 people and the sample is 453 people. The data used in the study was collected with two scales and through easy sampling method. In this study, explanatory and confirmatory factor analysis were used to determine the validity and reliability of the scales, correlation analysis was used to determine the relationships between the variables and structural equation model analysis methods were used in the structural analysis of the established model. The analyses performed in the study were done with the SPSS and AMOS package programs. At the end of the study, it was concluded that the Entrepreneurial Leadership scale is a one-dimensional scale, a factor explained the total variance of the model by $65.807 \%$, that the factor loads are above 0.7, and that the goodness of fit values are $\chi^{2} / d f: 2.758$, GFI: 0.973, CFI: 0.987, RMSEA: 0.062. In addition, it was concluded that the relationship between the variables was significant and moderate in the same direction $(r=0.445, p<0.01)$ and entrepreneurial leadership significantly affected individual performance.
\end{abstract}

Keywords: Entrepreneurial Leadership, Performance, Reliability, Validity.

Giriş

Günümüzde işletmeler arasında yoğun bir rekabet yaşanmaktadır. Böyle bir ortamda işletmeler varlığını sürdürmek için kendisini rakiplerinden farklılaştırmalıdır. Farklılık ise yenilik yapmakla ve risk almakla yakından ilgilidir. Girişimciliğin temelinde de yaratıcılık ve yenilik yapmak vardır. Bu kapsamda yeni fikirleri ürüne veya hizmete çevirmek, bu ürünü veya hizmeti pazara sunmak için 
Girişimci Liderlik Ölçeği’nin Geçerlik ve Güvenirlik Çalışması ve

Girişimci Liderliğin Bireysel Performansa Etkisi

“ticari bir teşebbüs kurmak ya da değer zincirine katkı sağlamak" girişimcilik olarak tanımlanır. Girişimci ise "pazarda bir firsatı gören ve bu firsatı değerlendirmek üzere örgüt kuran kişidir”. Örgüt kurulduktan sonra örgütün kuruluş amacını gerçekleştirmek için liderlik yapmak ise girişimci liderliktir. Kısaca girişimci lider, "yeni bir örgüt kuruncaya kadar girişimci, örgüt kurulduktan sonra liderdir". Birçok girişimcinin başarısız olmasının en önemli nedeni kurduğu örgütte liderlik rolünü oynayamamasından kaynaklanmaktadır.

Girişimci liderliğin örgütsel performansı olumlu yönde etkilediğine dair araştırmalar bulunmakla birlikte (Tarabishy vd., 2005; Jagdale ve Bhole, 2014; Rahim vd., 2015), bireysel performansı nasıl etkilediğine dair bir araştırmaya rastlanmamıştır. Girişimci liderlik, "çalıştığı kişileri girişimci olarak düşünme ve bu düşünceye uygun hareket etme sürecidir". Girişimci liderliğin davranışsal boyutları arasında "yenilikçilik, proaktifliklik, risk almak, özerlik ve sosyal ağları genişletmek" yer almaktadır. Bu kapsamda, girişimci liderliğin bireysel performansı da artıracağı değerlendirilmiştir.

\section{Kavramsal Çerçeve}

\section{Girişimcilik ve Girişimci Kavramı}

Günümüzde girişimcilik ekonomik büyümenin ve kalkınmanın önemli bir unsuru olarak değerlendirilmektedir. Hemen hemen tüm ülkeler girişimciliğin geliştirilmesi için büyük bir çaba harcamaktadır (Saygın ve Bekmezci, 2019: 112). Girişimcilik, fırsatların tespiti ile başlar (Uygun, 2018: 13). Fırsatların tespitini müteakip, bu firsatlardan faydalanmak gündeme gelir ki; bu kapsamda firsatlardan faydalanabilmenin yollarından biri de "işletme kurmak"tır. İşletme, başkalarının ihtiyacını karşılamak üzere mal veya hizmet üreten ekonomik birimdir (Mucuk, 2000: 4). Tanımda iki hususa vurgu yapılmıştır. Bunlardan birincisi, işletme, kendisi için değil, başkalarının ihtiyacını karşılamak için üretim yapar. Kendisi için üretim yapan birimler işletme olarak kabul edilemez. Üretim yapabilmek için emek, sermaye, doğal kaynaklar ve girişimcinin bir araya getirilmesi gerekir. Dolayısıyla, girişimcinin kendisi de üretim fonksiyonlarından birisidir ve emek, sermaye ve doğal kaynakları bir araya getirerek bu oluşum organize edilmektedir. İşletme tanımında yer alan ikinci husus ise işletmenin ekonomik bir birim olmasıdır. $\mathrm{Bu}$ da kıt kaynakların etkin ve verimli bir şekilde kullanılması ile ilgilidir. 
Girişimciliğin bugün bile üzerinde fikir birliğine varılmış bir tanımı bulunmamakla birlikte literatürde yer alan tanımlarda yaratıcılık, inovasyon, kişisel özellikler gibi kriterlere daha çok vurgu yapıldığ 1 görülmektedir (Fernald vd., 2005: 2). Girişimcilik, gelecekteki mal ve hizmetleri yaratma firsatlarının nasıl, kim tarafindan ve hangi yöntemlerle keşfedildiğinin bilimsel olarak incelenmesi, keşfedilmesi ve kullanılmasıdır (Shane ve Venkataraman, 2000: 218). Diğer bir anlatımla girişimcilik, "fikirleri yakalayıp, bunları ürüne ya da hizmete çevirme, sonrasında ise bu ürünü ya da hizmeti pazara sunacak bir ticari teşebbüs kurma" ya da "bir çalışanın örgütün değer zincirini geliştirici bir katkı sağlaması"dır (Şeşen ve Burmaoğlu, 2012: 366). Girişimciliğin, yeni istihdam yaratma, işsizliği azaltma, yeni mal ve hizmet üretme, ülkenin gelişmesine, pazar ekonomisine katkıda bulunma ve gelir dağılımını düzenleme gibi fonksiyonları bulunmaktadır (Akdoğan, 2019: 1920). Girişimci ise pazardaki firsatları gören, bu firsatları pazarlanabilen fikirlere dönüştürebilen, zaman içinde çaba, para ve yetenek ile değer katan, fikrin uygulanacağı rekabetçi pazarda riskleri üstlenen ve bu çaba karşısında ödülü fark eden yenilikçi veya geliştirici kişidir (Aydınlık, 2017: 1). Nitekim firsatları aramak, belirlenen hedeflere ulaşmak, bağımsız düşünmek, risk almak ve inovasyon yapmak girişimcilerin ortak özellikleri olarak belirtilmiştir (Fernald vd., 2005).

Fırsatları tespit etmek kadar firsatları yaratmak da önemlidir. Fırsatları görmek ve firsatları yaratmak ise gözlem, araştırma ve analiz yapmayı gerektirir. Gözlem, araştırma ve bu ikisinin analizi neticesinde ortaya bir fikir çıkar, bu fikrin hayata geçirilmesi durumunda bu fikir önem kazanır. Girişimciliğin tanımında yer alan işletme kurmak veya değer yaratmak da bu kapsamda değerlendirilmelidir. Dolayısıyla girişimci düşünmenin; yenilikçi ve yaratıcı olma, öncü olma, risk alma ve rekabetçi düşünme olmak üzere dört ana bileşeni olduğu söylenebilir (Erbaşlar, 2017: 5). Bu durumda girişimcilik bir eylem iken girişimci eylemi hayata geçiren kişidir (Ürper, 2015: 5).

Girişimci, fikirlerini hayata geçirdikten sonra, bu fikrin yaşatılması gerekir ki; burada fark yaratmak, yenilik yapmak, proaktif davranmak gibi konular gündeme gelir. Tüm bu konular da çalışanlar vasıtasıyla gerçekleştirilir. Girişimci kişilerde yazma, sözlü iletişim, organize etme gibi teknik becerilerin; planlama ve amaç oluşturma, karar verme, muhasebe-finansman gibi yönetim becerilerinin; risk alma, yenilikçi olma, vizyon sahibi bir lider olma gibi bireysel becerilerin de bulunması gerekir (Hisrich ve Peters, 2002: 21). Teknik ve yönetsel beceriler işletmenin kuruluş 
Girişimci Liderlik Ölçeği’nin Geçerlik ve Güvenirlik Çalışması ve

Girişimci Liderliğin Bireysel Performansa Etkisi

aşamasında, liderlik becerileri ise işletme kurulduktan sonra daha fazla önem arz etmektedir. Çünkü girişimcilik, işletme sahibi olmaktan, girişimci de yönetici olmaktan çok daha fazlasını ifade etmektedir. İşletme kurulduktan sonra, işletmenin varlığını sürdürebilmesi için girişimcinin liderlik yapması gerekir. Dolayısıyla girişimci, işletme kurarken müteşebbis, yönetim fonksiyonlarını uygularken yönetici, değişim yaratmak için takipçilerini etkilerken lider konumundadır.

\section{Girişimci Liderlik}

Girişimciliğin ve liderliğin öneminden dolayı bu iki kavram hem girişimcilik hem de liderlik davranışını birlikte araştırmak için birleştirilmiştir (Rahim vd., 2015: 195; Renko vd., 2015: 56). Nitekim girişimcilik ve liderliğin örtüştüğü alanlar; vizyon, firsat odaklılık, etki, planlama, motive etme, başarı yönelimi, yaratıcılık, esneklik, sabır, sebat, risk-alma, belirsizliğe karşı yüksek tolerans, azim, öz güven, güç yönelimi, proaktiflik, iç kontrol odağı olarak belirlenmiştir (Becherer vd., 2008; Cogliser ve Brigham 2004; Fernald vd., 2005). Ancak girişimci liderliği karakterize eden bu özellikler, firsatları tanıma ve firsatları kullanma olarak ifade edilebilecek girişimcilik hedeflerine odaklanmasıyla onu diğer liderlik türlerinden ayırmaktadır (Renko vd., 2015: 57). Girişimci liderlik, zorlu ve karmaşık ortamlarda inovasyon yapmayı ve firsatları belirlemeyi teşvik eden ve geliştiren etkili bir liderlik tarzı olarak tanımlanmıştır (Karol, 2015: 33; Fontana ve Musa, 2017: 2).

Her ne kadar liderlik, insanları belirlenen amaçlar doğrultusunda harekete geçirme süreci (Güney, 2015: 26) olarak tanımlansa da günümüzde liderlik, "insanları etkileme ve yapıyı harekete geçirme" sürecinden daha fazlasını gerektirmektedir. İnsanların bilgisi, becerisi, yeteneği, yönetim konusundaki algısı ve başarı ihtiyacı gibi pek çok husus değişmiştir. Dolayısıyla lider "düşünce oluşturan, takipçi de "işi yapan" kişi olmaktan çıkmıştır (Yılmaz, 2011: 5). Liderlik, takipçilerin gönüllü gayret göstermesini sağlama ve sosyal bir etkileşim sürecine dönüşmüştür. Girişimcinin liderliği de bu kapsamda değerlendirilmelidir. Çünkü girişimcinin kurduğu işletmenin başarılı olması için, işletmenin kuruluş motivasyonunu devam ettirmesi, girişimcinin de liderlik niteliklerini geliştirmesi gerekir. Nitekim girişimci liderlik, liderin birlikte çalıştığı kişileri girişimci olarak düşünmesi, birlikte çalıştığı kişilerin girişimci olarak hareket etmesi ve davranması cesaretini onlara aşılama sürecidir (Şeşen ve Burmaoğlu, 2012: 373). Diğer bir anlatımla girişimci liderlik, grup üyelerinin performansının, girişimcilik fırsatlarının 
tanınmasını ve kullanılmasını içeren örgüt hedeflerine ulaşılması konusunda yönlendirilmesi ve yönetilmesidir (Renko vd., 2015: 55). Gupta ve arkadaşları (2004: 242) da girişimci liderliği, katılımcıların desteğini almak ve katılımcıları harekete geçirmek için vizyoner senaryolar oluşturan liderlik tarzı olarak tanımlamıştır. Kısaca girişimci lider, firsat odaklı davranışlarda bulunur, bunu yaparken takipçilerini etkiler ve onların da girişimci davranışlar göstermesi konusunda onları motive eder ve cesaretlendirir. Bu haliyle girişimci liderlik, belirsiz bir iş ortamında tutarlı stratejiler ve benzersiz sonuçlar elde etmek için heterojen yeteneklerin kolektif bir şekilde daha yaratıcı ve yenilikçi çalışmasına odaklanan tek liderlik tarzı olarak ifade edilmiştir (Fontana ve Musa, 2017: 2).

Girişimci liderlik, başkalarıyla ilişkilerde liderin kişisel özelliklerinden veya tarzından daha fazlasını içerir. Girişimci liderlik, değişim ve değerleri aşılamak için net hedefler belirleme, firsatlar yaratma, personel güçlendirme, örgütsel samimiyeti koruma ve insan kaynakları sistemini geliştirme becerileri gibi hususları içerir (Cunningham ve Lischeron, 1991: 53). Literatürde girişimci liderliği tanımlamak için; "özellikler, kişilik, yetkinlik, ekonomik uyum, stratejik, yönetimsel ve davranışsal" olmak üzere altı farklı yaklaşım olduğu görülmüştür (Şeşen ve Burmaoğlu, 2012: 377-380). Özellikler yaklaşımı, girişimci liderlerin babalarının veya akrabalarının kendisine ait bir işyerinin bulunması, çoğunun erkek olması gibi diğerlerinden farklı demografik özelliklere sahip olduğunun; kişilik yaklaşımı, girişimci liderlerin değişim odaklı, yaratıcı, yüksek başarma ihtiyacı gibi özelliklerinin bulunduğunun; yetkinlikler yaklaşımı, girişimci liderlerin farklı yetkinliklere sahip olduğunun ve bu yetkinliklerin onları farklılaştırdığının; ekonomik uyum yaklaşımı, girişimci liderlerin risk alarak yenilik yaptığının ve bunun da üretici ve tüketici arasındaki dengeleri bozduğunun; stratejik yönetimsel yaklaşım, girişimci liderliğin işletmelerin rekabet üstünlüğü sağlamasında olası bir temel yetkinlik olabileceğinin; davranışsal yaklaşım da girişimci liderlerin neler yaptığının üzerinde durmuştur. Davranışsal boyutta da genellikle; risk alma, proaktiflik, vizyon sahibi olma, inovasyon, deneyim, karizma ve yaratıcılık konularının incelendiği söylenebilir (Esmer ve Dayı, 2017: 119). Şeşen ve Burmaoğlu (2012: 380), bunların dışında yenilikçilik, özerklik ve sosyal ağları geliştirme boyutları da girişimci liderin davranış boyutları arasında saymıştır.

Yapılan araştırmalarda, girişimci liderlik ile örgütsel performans arasında anlamlı bir ilişki bulunduğu (Jagdale ve Bhole, 2014; Rahim vd., 2015; Mgeni, 
Girişimci Liderlik Ölçeği’nin Geçerlik ve Güvenirlik Çalışması ve

Girişimci Liderliğin Bireysel Performansa Etkisi

2015), girişimci liderliğin çalışanların yenilikçi davranması ve firsatları tespit etmesi konusunda açık bir etkisinin olduğu (Bagheri, 2017), çalışanların yaratıcılık düzeyini kısmen artırdığı (Zorlu ve Tetik, 2018) ortaya konmuştur. Renko (2017: 25), bu liderlik tarzının genellikle büyümekte olan örgütlerde ortaya çıkan yanlış anlamaların ve çatışmaların üstesinden gelmede yardımcı olabileceğini, çalışanların iş tatminini ve performansını artırabileceğini, girişimci bir liderin altında çalışan her bir çalışanın işletmenin sorunlarına girişimci çözümler bulmaya çalışacağını, yine her bir çalışanın örgüt tarafından ele alınan yeni fikirlerin sayısını, dolayısıyla karar kalitesini ve fikirlere ilişkin içgörüyü potansiyel olarak geliştirmeye çalışacağını belirtmiştir.

Girişimci liderlikle ilgili; Fantona ve Musa (2017) tarafindan geliştirilmiş ölçek; stratejik, iletişimsel, motivasyonel ve kişisel/organizasyonel olmak üzere 4 boyuttan; Renko ve arkadaşları (2015) tarafından geliştirilmiş tek boyuttan; McGraw Hill Danışmanlık tarafından geliştirilmiş tek boyuttan (www.mhprofessional.com) oluşturulmuş ölçeklerden bazılarıdır.

\section{Bireysel Performans}

Bir işletmenin başarısı gösterdiği performansa bağlıdır. İşletmenin performansı da çalışanların performansına bağlıdır. İşletmedeki her bir çalışanın performans düzeyinin artırılması veya her bir çalışanın performansının etkin olarak kullanılması işletmenin de performansını artıracaktır (Barutçugil, 2002: 46). İşletmenin faaliyetleri, performans ölçümü ve performans hedeflerine ulaşıp ulaşmadığı performans ölçümü ile sürekli takip edilmelidir. Performans, çalışan tarafından amaçların ya da görevin yerine getirilme derecesidir (Bekmezci, 2020: 17). Diğer bir anlatımla performans, bir çalışanın veya bir grubun, ilgili olduğu birimin ve organizasyonun amaçlarına niteliksel ve niceliksel katkısının toplam ölçüsüdür (Çalık, 2003: 8).

Geleneksel anlamda iş performansı, kişisel seviyede işin gereklerinin yerine getirilmesi şeklinde değerlendirilirken, son zamanlardaki eğilim, görev performansı dışında çalışanın işletmenin etkin bir şekilde işleyişine katkıda bulunan davranışlarına da odaklanmıştır (Viswesvaran, 2009: 143). İş performansı, farklı boyutlarla ele alınmış olmakla birlikte en çok dikkat çeken çalışmalardan biri performansin görev (task) performansı ve bağlamsal (contextual) performans (Motowidlo ve Van Scotter, 1994) olmak üzere iki boyutta ele alındığı çalışma 
olmuştur (Beffort ve Hattrup, 2003: 17). Kısaca görev performansı; çalışanın görevleri dahilinde tanımlanan faaliyetlerde, bağlamsal performans ise örgüt kültürüne ve iklimine katkıda bulunma, gönüllü olarak fazladan iş yapma, şevkle çalışma, yardımlaşma, kurallara ve süreçlere uyma gibi üretkenlik sağlayan işletme içindeki diğer faaliyet ve davranışlarla ilgilidir. Bağlamsal performans kapsamında Smith ve arkadaşları (1983)'nın popüler hale getirdiği “Örgütsel Vatandaşlık Davranışı”, çalışanların gönüllü olarak gerçekleştirdiği ve örgütsel etkinliğe katkıda bulunan görev dışı davranışlar olarak tanımlanan "Örgütsel Spontanlık" (George ve Brief, 1992), Van Dyne ve arkadaşları (1995)'nın ortaya koyduğu “Ekstra Rol Davranışları" ile inisiyatif kullanma, kurallara uyma, sorumluluk alma gibi çalışma disiplini ve motivasyonu ile ilgili davranışları ifade eden "İşe Kendini Adama" (Barutçugil, 2002: 47) sayılabilir.

Literatürde örgütsel etkinlik açısından olumsuz etkisi olan; hırsızlık (Clark ve Hollinger, 1983), mala ve mülke zarar verme, işyerinde şiddet (Sacket ve Wanek, 1996), işi aksatma, kaçınma veya çaba göstermeme eğilimi (Kidwetl ve Benett, 1993) gibi davranışlar da bireysel performansı oluşturan boyutlar olarak ele alınmıştır.

Bireysel performansın; kişilerarası kararlar, bireysel kararlar, sistem sürdürme ve belgeleme olmak üzere dört kategoride kullanım alanı bulunmaktadır (Viswesvaran, 2009: 137-138). Kişilerarası kararların kullanım alanlarını bireysel performans verilerinin ücret yönetimi, terfi kararları ve liyakat temelli ödeme sistemlerinin tasarlanmasını içermektedir. Bireysel kararlar, bireylerin güçlü ve zayıf yanlarını belirlemek için geri bildirim sağlanmasını içermektedir- daha sonra eğitim ve yerleştirme araçlarını değerlendirmek için kullanılan verilerdir. Sistem sürdürme, insan kaynakları planlaması ve yönetim yapılarının güçlendirilmesinde bireysel performans değerlendirmelerinden yararlanılması ile ilgilidir. Son olarak, bireysel performans verileri aynı zamanda hukuki belgeleme amacıyla da kullanılmaktadır.

Bireysel performans değerlendirmesi, "bireyden beklenen ile bireyin ulaştığı sonucun karşılaştırılması" şeklinde tanımlanırken "bireyin yeteneklerinin, işin nitelik ve gereklerine ne ölçüde uyduğunu araştıran, bireyin işteki başarısını saptamaya çalışan objektif analizler" şeklinde de tanımlanmaktadır (Köksal, 2005: 72). Literatürde iş performansının; kendi kendini değerlendirme, yöneticinin değerlendirmesi, objektif performans ölçümleri (örneğin satış miktarı) ve iş 
Girişimci Liderlik Ölçeği’nin Geçerlik ve Güvenirlik Çalışması ve

Girişimci Liderliğin Bireysel Performansa Etkisi

performans1 ile ilgili genel değerlendirmeler (diğer üçünün herhangi bir kombinasyonunu içeren) şeklinde ele alındığı görülmektedir (Gilbao ve Shirom, 2008: 228). Ancak burada önemli olan, bireysel iş performansı, değerlendirilebilir davranışlar olarak ele alınmalı, bireyin kontrolü dışında olan davranışlar bireysel performansa dahil edilmemelidir (Viswesvaran, 2009: 140).

Bireysel performansı oluşturan üç unsur bulunmaktadır (Barutçugil, 2002: 48): "Odaklanma, yetkinlik ve adanma". Odaklanma, çalışanın ne yapacağını bilmesi; yetkinlik, çalışanın görevini yapabilecek becerilere sahip olması; adanma ise çalışanın katkıda bulunmaya istekli olmasıdır. Bu üç unsur ayrı ayrı ya da birlikte düşünülebilir. Yüksek bir bireysel performans için bu üç unsurun bir arada olması gerekir. Ancak farklı durumlarda bu unsurların bileşimi, diğer bir anlatımla önem ve ağırlığı farklılık arz edebilir. Bu durumda yönetimin niteliği ve düzeyi değişmelidir. Bireysel performansın artırılması da çalışanın neye katkı sağlayacağını bilmesine, katkıda bulunup bulunamayacağına ve katkıda bulunma konusunda istekli olup olmadığına bağlı olacaktır.

Bireysel performansı ölçmek üzere geliştirilmiş ölçeklerden bazıları; Kane (1986) tarafından geliştirilmiş ölçek, "kalite, nicelik, dakiklik, maliyet etkinliği, denetim ihtiyacı ve kişilerarası etki olmak" üzere 6 boyutlu; Murphy (1989) tarafından geliştirilmiş ölçek, "işi aksatma davranışları, görev performansı, kişilerarası davranışlar ve zararlı davranışlar" olmak üzere 4 boyutlu; Campbell (1990) tarafından geliştirilmiş ölçek, "işe özgü görev yeterliliği, işe özgü olmayan görev yeterliliği, yazılı ve sözlü iletişim, çaba gösterme, kişisel disiplin, çalışma arkadaşlarının ve ekibin performansına katkıda bulunma, denetim ve yönetim" olmak üzere 7 boyutlu; Welbourn ve arkadaşları (1997) tarafından geliştirilmiş ölçek, "işe özgü bilgi, kariyerde ilerlemek için gerekli nitelikler, yaratıcılık ve iş arkadaşları ile ilişkiler" olmak üzere dört boyutlu; Yelboğa (2003) tarafindan geliştirilmiş ölçek, "yönetsel yeterlilikler, işe yönelik bilgi/beceri yeterlilikleri, davranış yeterlilikleri ve kendini geliştirme yeterlilikleri" olmak üzere 4 boyutludur.

Girişimci liderliğin örgütsel performansı artırdığına dair araştırmalar, doğal olarak girişimci liderliğin bireysel performansını da artırdığını düşündürmektedir. Nitekim, girişimci liderin, birlikte çalıştığı kişileri de girişimci olarak düşünmesi, onların girişimci olarak hareket etmesini ve davranmasını cesaretlendirmesi çalışanların da girişimci özelliklerinden olan yaratıcılık, esneklik, risk alma, başarma 
ihtiyac1, azim, proaktiflik gibi davranışları sergilemesini gerektirir. Yine girişimci liderlerin net hedefler belirlemesi ve personelini güçlendirmesi de çalışanların bireysel performansını artıran uygulamalardır. Ancak yukarıda da belirtildiği üzere girişimci liderlikle ilgili yapılan çalışmalardan biri girişimci liderliğin çalışanların yaratıcılığını kısmen artırdığını göstermiştir. Verilen bilgiler ve yapılan araştırmalar doğrultusunda araştırma sorusu: "Girişimci liderlik bireysel performansı etkiler mi?" şeklinde belirlenmiştir.

\section{Araştırmanın Yöntemi}

Girişimci liderliğin bireysel performansa etkisini belirlemeye yönelik yapılan bu araştırmada, önce Renko ve arkadaşları (2015) tarafindan geliştirilen Ek’te verilen "Girişimci Liderlik Ölçeği”" Türkçeye uyarlanmış, müteakiben söz konusu ölçeğin geçerliği ve güvenirliği ile ilgili anket çalışmaları yapılmış ve son olarak örneklemden elde edilen verilere göre girişimci liderliğin bireysel performansa etkisi belirlenmeye çalışılmıştır. Yapılan analizlerde açıklayıcı ve doğrulayıcı faktör analizi, korelasyon analizi ve yapısal eşitlik modeli yöntemleri kullanılmıştır.

\section{Araştırmanın Ana Kütlesi ve Örneklemi}

Yapılan araştırmanın ana kütlesini Mersin'de faaliyette bulunan çeşitli lojistik firmalarında çalışan kişiler oluşturmaktadır. Çalışma ana kütlesinin eleman sayısı sınırlı olup Mersin Ticaret ve Sanayi Odasından alınan verilere göre yaklaşık 2000 kişiden oluşmaktadır. Örneklem büyüklüğünün hesaplanmasında, ana kütleden $\% 95$ güvenirlik sınırları içinde $\% 5$ 'lik bir hata payı dikkate alınmış ve örneklem büyüklüğü 322 kişi (Sekaran, 1992: 253) olarak hesaplanmıştır. Bu örneklemin belirlenmesinde kolayda örneklem yöntemi tercih edilmiştir. Çünkü literatürde, verilerin kısa zamanda ve en az maliyetle elde edilmesine ihtiyaç duyulduğunda, olasıllğa dayanmayan kolayda örnekleme yöntemi ile verilerin toplanabileceği ifade edilmektedir (Eygü ve Kılınç, 2019: 1027). Bu kapsamda, 01 Haziran-30 Ağustos 2019 tarihleri arasında 600 anket sahaya sürülmüştür. Anketlerin toplanmasında web tabanlı anket tekniği kullanılmıştır. Verilen cevaplardan 453’ü analize tabi tutulmuştur.

Araştırmaya katılanların; \%69,5 (n=315)'i erkek, \%30,5 (n=138)'i kadın; $\% 57,1$ (n=279)'i evlidir. Çalışanların \%0,7 (n=3)'si ilköğretim, \%14,3 (n=65)'ü lise, $\% 66,7$ (n=302)'si üniversite, $\% 18,4$ (n=83)'ü lisansüstü eğitim derecesine; \%13,5 
Girişimci Liderlik Ölçeği’nin Geçerlik ve Güvenirlik Çalışması ve

Girişimci Liderliğin Bireysel Performansa Etkisi

(n=61)'i 18-25, \%25,6 (n=116)'s1 26-30, \%42,6 (n=193)'s1 31-40, \%12,8 (n=58)'i 41-50 ve \%5,5 (n=25)'i 51-60 yaş aralığındadır; \%17,4 $(\mathrm{n}=79)^{\prime}$ 'ü 3 yıldan az, \%16,3 (n=74)'ü 3-5 yıl, \%23,2 (n=105)'si 6-10 y11, \%23,4 (n=106)'ü 11-15 yıl ve \%19,6 $(\mathrm{n}=89)$ 's 16 y1l ve üzeri iş deneyimine sahiptir.

\section{Araştırmanın Aşamaları}

Araştırma, üç aşamada gerçekleştirilmiştir. Birinci aşamada; Girişimci Liderlik Ölçeği’nin Türkçeye uyarlanması ile geçerliği uzman görüşü ve açıklayıcı faktör analizi ile, ikinci aşamada; Girişimci Liderlik Ölçeği ve Bireysel Performans Ölçeği ile ilgili elde edilen verilerin uygunluğu doğrulayıcı faktör analizi ile ve üçüncü aşamada değişkenler arasında kurulan ilişkinin yapısı korelasyon analizi ve yapısal eşitlik modeli yöntemleri ile incelenmiştir.

\section{Araştırmanın Ölçekleri}

Girişimci Liderlik Ölçeği ve Bireysel Performans Ölçeği olmak üzere iki ölçek kullanılmıştır. Söz konusu ölçekler ile ilgili detaylı bilgiler ile ölçeklerin geçerlik ve güvenirlik çalışmaları kapsamında yapılanlar analizler ve elde edilen sonuçlar müteakip bölümlerde verilmiştir.

\section{Girişimci Liderlik Ölçeği}

Girişimci liderlik davranışını ölçmek üzere Renko ve arkadaşları (2015) tarafindan geliştirilen "Girişimci Liderlik Ölçeği (ENTRELEAD)" kullanılmıştır. Ölçekte, girişimcilik fırsatları hakkında liderin doğrudan katkısını belirleyebilmek için katılımcıların liderlerini girişimci liderliğin dört kritik özelliği olan risk alma, yaratıcılık, tutku ve vizyon açısından değerlendirmesine yönelik sorular bulunmaktadır. Ayrıca ölçek, girişimci liderlerin, takipçilerin işlerini yapmaktan başka mevcut iş yapma yollarına meydan okumasını beklediğini, takipçilerinin girişimcilik fırsatlarını tanımasına ve kullanmasına imkân verdiğini kabul etmektedir (Renko, 2017: 32). ENTRELEAD, tek boyuttan ve 8 sorudan oluşan, 5'li Likert tipi (1=Kesinlikle Katılmıyorum, 5=Kesinlikle Katılıyorum) bir ölçektir. Ölçek, 367 kişiden ve 208 kişiden oluşan iki farklı örneklem üzerinde uygulanmış, ölçeğin Cronbach alfa değeri birinci örneklem için 0,90 , ikinci örneklem için 0,93 olarak rapor edilmiştir. 
Ölçeğin geçerlik ve güvenirlik çalışması bu makalenin yazarları tarafından gerçekleştirilmiştir. Bu kapsamda; ölçeğin tercümesi, açıklayıcı faktör analizi, doğrulayıcı faktör analizi ve güvenirlik analizi yapılmıştır.

Ölçek, önce Türkçeye uyarlanmıştır. Ölçek tercüme edilirken, Brislin (1970) tarafından önerilen yöntem kullanılmıştır. Ölçek 3 öğretim elemanı tarafından ayrı ayrı Türkçeye çevrilmiş, bu çeviriler karşılaştırılmış ve ölçeğin Türkçe ilk versiyonu oluşturulmuştur. Bu ölçek, İngilizceyi çok iyi seviyede bilen 3 farklı kişi tarafından Türkçeden İngilizceye çevrilmiş, orijinal hali ile karşılaştırılmıştır. Türkçe çevirisi yapılarak son şekli verilen ölçek, odak grup çalışması ile test edilmiştir.

Müteakiben ölçeğin geçerlik ve güvenirlik çalışması yapılmıştır. Ölçeğin kapsam ve mantıksal geçerliği için uzman görüşüne başvurulmuş, yapı geçerliği için açıklayıcı ve doğrulayıcı faktör analizi yapılmıştır. Güvenirlik analizi için Cronbach alfa katsayısı hesaplanmıştır.

Ölçeğin yapı geçerliği kapsamında yapılan açıklayıcı faktör analizi ile ilgili olarak Kaiser-Meyer-Olkin (KMO) ve Barlett testi yapılmış ve elde edilen sonuçlar değerlendirilmiştir. Kaiser-Meyer-Olkin (KMO) ve Barlett testi ile örneklemin açıklayıcı faktör analizi için uygun büyüklük ve nitelikte olması denenir (Pallant, 2017; Tabachnick ve Fidell, 2001). Ölçeğin Kaiser-Meyer-Olkin (KMO) katsayısı 0,931 ve Bartlett küresellik testinin istatistik değeri ve anlamlılık düzeyi $X^{2}{ }_{(28)}=2417,086$ ve $\mathrm{p}=0,000$ olarak hesaplanmıştır. $\mathrm{Bu}$ sonuç, örneklem verilerinin faktör analizi için uygun olduğunu göstermektedir.

Açıklayıcı faktör analizinde Kaiser-Meyer-Olkin (KMO) ve Barlett testi sonuçlarına bakıldıktan sonra verilerin kaç faktör altında toplandığı, madde faktör yüklerinin hangi değerler arasında olduğu ve faktör yüklerinin toplam varyansın ne kadarını açıklayabildiğine bakılması gerekmektedir. Açıklayıcı faktör analizi ile ilgili literatürde madde faktör yüklerinin alması gereken en düşük değerin " 0,30 " olduğu kabul edilirken; öz değerleri " 1 "den büyük faktörler üzerinde uygulama yapılmalıdır (Alyılmaz ve Polatcan, 2018; Neale ve Liebert, 1980; Pallant, 2017; Tabachnick ve Fidel, 2001). Bu nedenle açıklayıcı faktör analizi sonucunda ulaşılan madde faktör yükleri 0,30'un altında olan maddeler ile öz değerleri 1'den düşük olan faktörler değerlendirilmeye alınmamıştır. Açıklayıcı faktör analizinde temel bileşenler analizi ve Varimax faktör döndürme yöntemi kullanılmıştır. 
Girişimci Liderlik Ölçeği’nin Geçerlik ve Güvenirlik Çalışması ve Girişimci Liderliğin Bireysel Performansa Etkisi

Tablo 1. Girişimci Liderlik Ölçeği’ne Ait Faktör Yükleri ve Açıklanan Toplam Varyans

\begin{tabular}{|c|c|c|c|c|c|c|}
\hline $\begin{array}{c}\text { Faktör } \\
\text { Yükleri }\end{array}$ & $0,954,0,944,0,932,0,901,0,845,0,821,0,805,0,794$ \\
\hline \multicolumn{7}{|c|}{ Özdeğerler } \\
\hline Faktör & Toplam & $\begin{array}{c}\text { \% } \\
\text { Varyans }\end{array}$ & $\begin{array}{c}\text { \% } \\
\text { Kümülatif }\end{array}$ & Toplam & $\begin{array}{c}\text { \% } \\
\text { Varyans }\end{array}$ & $\begin{array}{c}\text { \% } \\
\text { Kümülatif }\end{array}$ \\
\hline 1 & 5,265 & 65,807 & 65,807 & 5,265 & 65,807 & 65,807 \\
\hline 2 & 0,619 & 7,736 & 73,547 & & & \\
\hline 3 & 0,521 & 6,511 & 80,053 & & & \\
\hline 4 & 0,475 & 5,942 & 85,996 & & & \\
\hline 5 & 0,353 & 4,410 & 90,406 & & & \\
\hline 6 & 0,315 & 3,938 & 94,344 & & & \\
\hline 7 & 0,243 & 3,035 & 97,379 & & & \\
\hline 8 & 0,210 & 2,621 & 100,000 & & & \\
\hline
\end{tabular}

Tablo 1'de yer alan değerlere bakıldığında; ölçeğin tek faktörlü olduğu, faktör yüklerinin 0,794-0,954 arasında değerler aldığ 1 ve faktör yüklerinin hepsinin 0,70 'in üstünde olduğu, bu tek faktörlü yapının toplam varyansın $\% 65,807$ 'sini açıkladığı tespit edilmiştir.

Temel bileşen analizi ile açıklayıcı faktör analizi yapıldıktan sonra AMOS programında doğrulayıcı faktör analizi yapılmıştır. Doğrulayıcı faktör analizi, açıklayıcı faktör analizi ile belirlenen faktörlerin hipotez ile belirlenen faktör yapılarına uygunluğunu test etmek için kullanılan faktör analizidir. Açıklayıcı faktör analizi, hangi değişken gruplarının, hangi faktör ile yüksek düzeyde ilişkili olduğunu test etmek için kullanılırken, belirlenen "k" sayıda faktöre katkıda bulunan değişken gruplarının, bu faktörler ile yeterince temsil edilip edilmediğinin belirlenmesi için doğrulayıcı faktör analizinden faydalanılır. Bu kapsamda doğrulayıcı faktör analizi sonucunda elde edilen ölçeğe ait uyum iyilik değerleri Tablo 2'de verilmiştir.

Tablo 2. Girişimci Liderlik Ölçeği Uyum İyilik Değerleri

\begin{tabular}{|c|c|c|c|c|}
\hline Ölçek* & $\begin{array}{c}\chi^{\mathbf{2}} / \mathbf{d f} \\
<\mathbf{5}\end{array}$ & $\begin{array}{c}\text { GFI*** } \\
>, \mathbf{8 5}\end{array}$ & $\begin{array}{c}\text { CFI** } \\
>\mathbf{9 0}\end{array}$ & $\begin{array}{c}\text { RMSEA** } \\
<, \mathbf{0 8}\end{array}$ \\
\hline Girişimci Liderlik Ölçeği & 2,758 & 0,973 & 0,987 & 0,062 \\
\hline
\end{tabular}

* Uyum iyiliği değerleri "kabul edilebilir" standartlara göre düzenlenmiştir.

** RMSEA: Root Mean Square Error of Approximation (Yaklaşık Hataların Ortalama Karakökü); GFI: Goodness of Fit Index (Uyum İyiliği İndeksi); CFI: Comparative Fit Index (Karşılaştırmalı Uyum İndeksi). 
Tablo 2'de yer alan Girişimci Liderlik Ölçeği'nin yapı geçerliği kapsamında yapılan doğrulayıcı faktör analizi sonucunda elde edilen uyum iyilik değerleri incelendiğinde, modele ait uyum iyiliği değerlerinin kabul edilebilir olduğu tespit edilmiş ve doğrulayıcı faktör analizi modelinin uyum ölçek değerleri yeterli bulunmuştur.

Modelin geçerliği kapsamında ayrıca yakınsama geçerliği (standart faktör yükleri ve açıklanan ortalama varyans değeri (AVE)) değerleri ile ayrışma geçerliği değerlerine de bakılmıştır. Bu kapsamda yakınsama geçerliği ile ilgili hesaplanan istatistiki değerler Tablo 3'te verilmiştir.

Tablo 3. Doğrulayıcı Faktör Analizi Faktör Yükleri Sonuçları

\begin{tabular}{|c|c|c|}
\hline Sorular & $\begin{array}{c}\text { Standartlaştırılmış } \\
\text { Faktör } \\
\text { Yükleri }\end{array}$ & $\begin{array}{c}\text { Standartlaştırılmamış } \\
\text { Faktör Yükleri }\end{array}$ \\
\hline $\mathbf{1}$ & 0,757 & 0,995 \\
\hline $\mathbf{2}$ & 0,768 & 1,032 \\
\hline $\mathbf{3}$ & 0,714 & 1,063 \\
\hline $\mathbf{4}$ & 0,873 & 1,153 \\
\hline $\mathbf{5}$ & 0,792 & 1,014 \\
\hline $\mathbf{6}$ & 0,880 & 1,201 \\
\hline $\mathbf{7}$ & 0,800 & 1,085 \\
\hline $\mathbf{8}$ & 0,641 & 1,000 \\
\hline
\end{tabular}

Tablo 3'te yer alan yakınsama geçerliği değerleri incelendiğinde, verilen doğrulayıcı faktör modeline ait standart faktör yüklerinin 0,60'nın üzerinde olduğu görülmektedir. Standart faktör yüklerinin 0,50'nin üzerinde ve uyum ölçeği değerlerinin referans değerleri içinde olması, ölçeğin yakınsama geçerliğini göstermektedir. Yakınsama geçerliğinin bir diğer göstergesi olan açıklanan ortalama varyans (AVE) değeri ise 0,61 olarak hesaplanmıştır. Yakınsama geçerliğinin teyit edilebilmesi için açıklanan ortalama varyans değerinin 0,50 ya da 0,50 'den fazla olmas1 gerekir (Civelek, 2018: 42). Bu bulgu ölçeğin yakınsama geçerliğini göstermektedir. Ayrışma geçerliği için de "veri setindeki her bir boyut için AVE değerlerinin karekökü alındığında, bu değerlerin o boyutun diğer boyutlarla olan korelasyon katsayılarından büyük olması" istenmektedir. Bu durumda kullanılan ölçeklerin her bir boyut için ayrışma geçerliğine sahip olduğu söylenebilir. AVE 
Girişimci Liderlik Ölçeği’nin Geçerlik ve Güvenirlik Çalışması ve

Girişimci Liderliğin Bireysel Performansa Etkisi

değerinin karekökü $(0,78)$, korelasyon değerinden büyüktür $(0,451)$. Bu bulgu ölçeğin ayrışma geçerliğinin olduğunu göstermektedir.

Güvenirlik analizi neticesinde ölçeğin Cronbach alfa katsayısı 0,923 olarak hesaplanmış, ölçeğin yüksek güvenirliğe sahip olduğu sonucuna ulaşılmıştır. Ayrıca birleşik güvenirlik (Composite Realiability-CR) değerinin 0,70'in üzerinde olması da kullanılan ölçeğin güvenirliğini göstermektedir. Bu çalışmada birleşik güvenirlik değeri 0,76 olarak hesaplanmıştır.

Girişimci Liderlik Ölçeği kapsamında yapılan analizler sonucunda elde edilen değerlere bağlı olarak sonuçta standart faktör yüklerinin 0,50'nin üzerinde olması, uyum iyilik değerlerinin referans değerleri içinde bulunması, AVE değerinin karekökünün korelasyon değerinden büyük olması, Cronbach alfa ve birleşik güvenirlik ve Cronbach alfa değerlerinin eşik değer olan 0,70'in üzerinde olması Girişimci Liderlik Ölçeği'nin geçerli ve güvenilir olduğunu göstermektedir.

\section{Bireysel Performans Ölçeği}

Bireysel performansın ölçülmesi amacıyla çalışmada kullanılan İş Performansı Ölçeği, Kirkman ve Rosen (1999) tarafından oluşturulmuş, aynı ölçek daha sonra ayrı bir çalışmada Sigler ve Pearson (2000) tarafından kullanılmıştır (Çalışkan ve Akkoç, 2012). Bu ölçek, tek boyuttan ve 4 sorudan oluşan, 5'li Likert tipi (1=Kesinlikle Katılmıyorum, 5=Kesinlikle Katılıyorum) bir ölçektir. Ölçeğin güvenirlik katsayısının her iki çalışmada da 0,70'in üstünde olduğu belirtilmiştir. $\mathrm{Bu}$ ölçek, Türkçeye uyarlanarak, Çöl (2008) tarafindan akademisyenler üzerinde yapılan, Çalışkan ve Akkoç (2012) tarafından da yazılım sektöründe yapılan araştırmada kullanılmış, ölçeğin Cronbach alfa katsayısı değerleri 0,82 ve 0,65 olarak rapor edilmiştir. Bu çalışmada, ölçeğin Cronbach alfa katsayısı 0,867 olarak hesaplanmış, ölçeğin yüksek güvenirliğe sahip olduğu sonucuna ulaşılmıştır. Yapılan doğrulayıcı faktör analizi neticesinde; uyum iyilik değerlerinin referans değerleri arasında olduğu tespit edilmiştir. Bireysel Performans Ölçeğine ait uyum iyilik değerleri Tablo 4'te verilmiştir. 
Tablo 4. Bireysel Performans Ölçeği Uyum İyilik Değerleri

\begin{tabular}{|c|c|c|c|c|}
\hline Ölçek & $\begin{array}{c}\chi^{\mathbf{2}} / \mathbf{d f} \\
<\mathbf{5}\end{array}$ & $\begin{array}{c}\text { GFI } \\
>, \mathbf{8 5}\end{array}$ & $\begin{array}{c}\text { CFI } \\
>, \mathbf{9 0}\end{array}$ & $\begin{array}{c}\text { RMSEA } \\
<, \mathbf{0 8}\end{array}$ \\
\hline Bireysel Performans Ölçeği & 1,356 & 0,997 & 0,999 & 0,028 \\
\hline
\end{tabular}

Bulgular

Araştırma kapsamında elde edilen veriler SPSS ve AMOS programları kullanılarak analiz edilmiştir. Katılımcıların algıladığı girişimci liderlik davranışı ile bireysel performansa ilişkin elde edilen verilerin ortalamasına, standart sapmasına ve korelasyona bakılmış, müteakiben girişimci liderliğin bireysel performansı ne kadar belirlediğini incelemek üzere yapısal eşitlik modeli kullanılmıştır.

Verilere ilişkin ortalama, standart sapma ve korelasyon değeri Tablo 5'te verilmiştir. Tablo 5 'te yer alan değerlerin hesaplamasında gizli değişkenlerin sayısal değeri olarak ölçülebilen değişkenlerin değerlerinin toplam değerleri kullanılmış ve bu nedenle Pearson korelasyon katsayısı hesaplanarak yorumlanmıştır.

Tablo 5. Verilere İliş̧kin Ortalama, Standart Sapma ve İlişki Değerleri

\begin{tabular}{|c|c|c|c|c|}
\hline Değişken & Ortalama & $\begin{array}{c}\text { Standart } \\
\text { Sapma }\end{array}$ & $\begin{array}{c}\text { Girişimci } \\
\text { Liderlik }\end{array}$ & $\begin{array}{c}\text { Bireysel } \\
\text { Performans }\end{array}$ \\
\hline Girişimci Liderlik & 3,94 & 0,911 & 1 & $0,451^{* *}$ \\
\hline $\begin{array}{c}\text { Bireysel } \\
\text { Performans }\end{array}$ & 4,37 & 0,699 & $0,451^{* *}$ & 1 \\
\hline
\end{tabular}

** $\mathrm{p}<0,01$

Tablo 5'te yer alan değişkenler incelendiğinde iki değişken arasında anlamlı ve aynı yönde bir ilişki olduğu görülmektedir.

İki değişken arasındaki nedensellik ilişkisi yapısal eşitlik modeli ile incelenmiş, AMOS paket programında yapılan analizin grafiksel gösterimi Şekil 1'de verilmiştir. Şekil 1'de kullanılan değerlerin hepsi standardize edilmiş değerlerdir. Analizde parametreler en çok olabilirlik yöntemi ile tahmin edilmiştir. 
Girişimci Liderlik Ölçeği’nin Geçerlik ve Güvenirlik Çalışması ve

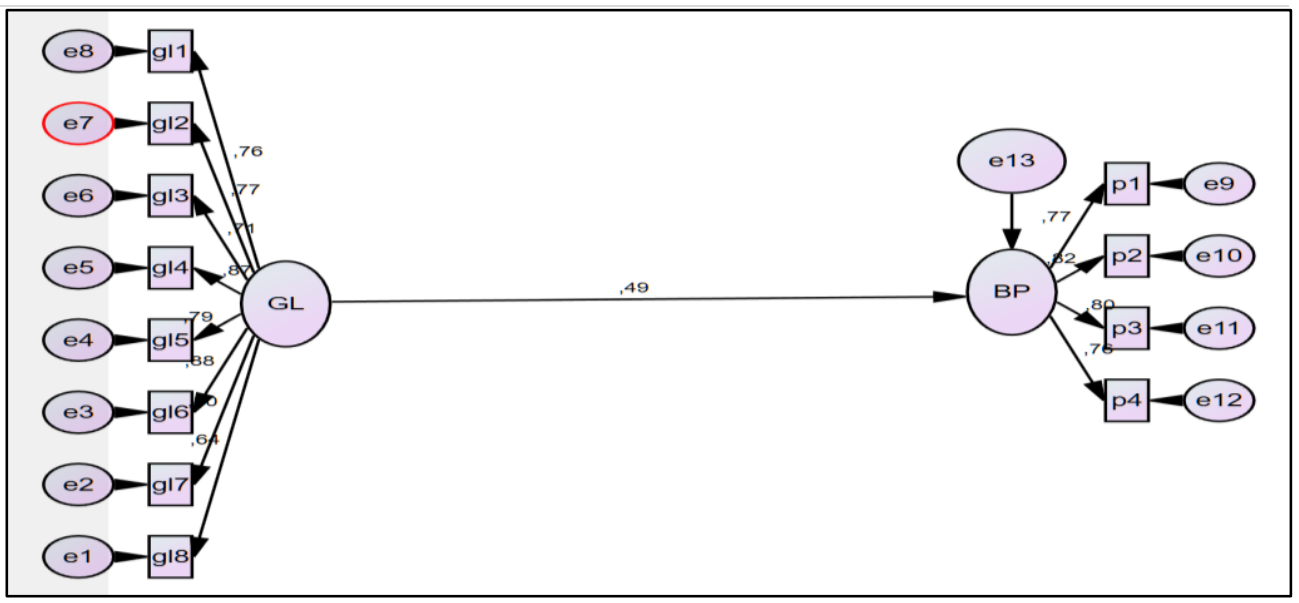

Şekil 1. Girişimci Liderlik ile Bireysel Performans Değişkenlerinin Yapısal Eşitlik Modeli

Şekil 1'de yer alan modelde ilk olarak gizli değişkenler ile ölçülebilir değişkenler arasındaki standartlaştırılmış faktör yüklerine bakılmıştır. Bu kapsamda elde edilen standartlaştırılmış faktör yüklerinin değerleri Tablo 6'da yer almaktadır.

Tablo 6. Modele Ait Standartlaştırılmış Faktör Yükleri

\begin{tabular}{|c|c|c|c|}
\hline \multicolumn{3}{|c|}{ Ölçülebilir ve Gizli Değişkenler } & $\begin{array}{c}\text { Standartlaştırılmış Faktör } \\
\text { Yükleri }\end{array}$ \\
\hline $\mathrm{g} 18$ & $\leftarrow$ & \multirow{8}{*}{ GL } & 0,643 \\
\hline g17 & $\leftarrow$ & & 0,800 \\
\hline g16 & $\leftarrow$ & & 0,875 \\
\hline gl5 & $\leftarrow$ & & 0,795 \\
\hline $\mathrm{gl} 4$ & $\leftarrow$ & & 0,872 \\
\hline gl3 & $\leftarrow$ & & 0,715 \\
\hline $\mathrm{g} 12$ & $\leftarrow$ & & 0,771 \\
\hline g11 & $\leftarrow$ & & 0,760 \\
\hline p1 & $\leftarrow$ & \multirow{4}{*}{ BP } & 0,767 \\
\hline $\mathrm{p} 2$ & $\leftarrow$ & & 0,823 \\
\hline p3 & $\leftarrow$ & & 0,802 \\
\hline p4 & $\leftarrow$ & & 0,765 \\
\hline
\end{tabular}


Tablo 6'da yer alan değişkenler incelendiğinde, standartlaştırılmış faktör yüklerinin literatürde kabul edilen referans değerleri ile uyumlu olduğu görülmüştür. Doğrulayıcı faktör analizinin sonucunda elde edilen standartlaştırılmış madde faktör yüklerinin 0,70 ve üzerinde olması ilgili maddelerin kurulan yapısal eşitlik modeli için anlam taşıdığını ifade etmektedir (Güngören, Bektaş, Öztürk \& Horzum, 2014; Özdamar, 2017; Yaşlığlu, 2017)

Modele ait standartlaştırılmış faktör yüklerinin kontrol edilmesini müteakip modelin uyum değerlerine bakılması gerekmektedir. Modele ait uyum iyiliği değerleri Tablo 7'de gösterilmiştir.

Tablo 7. Modele Ait Uyum İyiliği Değerleri

\begin{tabular}{|c|c|c|c|c|}
\hline Ölçek & $\begin{array}{c}\chi^{2} / \mathbf{d f} \\
<\mathbf{5}\end{array}$ & $\begin{array}{c}\text { TLI } \\
>, 90\end{array}$ & $\begin{array}{c}\text { CFI } \\
>, 90\end{array}$ & $\begin{array}{c}\text { RMSE } \\
\mathbf{A} \\
<, \mathbf{0 8}\end{array}$ \\
\hline Girişimci Liderlik Ölçeği & 3,042 & 0,953 & 0,968 & 0,067 \\
\hline
\end{tabular}

NOT: Uyum iyiliği değerleri "kabul edilebilir" standartlara göre düzenlenmiştir.

Tablo 7'de oluşturulan modele ait uyum iyiliği değerleri incelendiğinde söz konusu değerlerin literatürde kabul edilebilir sınırlar içerisinde olduğu görülmektedir. Dolayısıyla modelin test edilmesinde kullanılan verilerin model ile uyumlu olduğu sonucuna varılmıştır.

Kurulan modelin uyum iyiliği değerlerinin incelenmesini müteakip gizli değişkenler arasındaki standartlaştırılmış Beta katsayısına ve bu katsayının anlamlılık düzeyinin anlamlılığına bakılması gerekmektedir. Bu kapsamda kurulan modelde yer alan girişimci liderlik ve bireysel performans gizli değişkenleri arasındaki standartlaştırılmış Beta katsayısı ile bu katsayının anlamlılığı ile ilgili hesaplanmış istatistik değerler Tablo 8'de gösterilmiştir.

Tablo 8. Modele Ait Toplam ve Doğrudan Etki Değerleri

\begin{tabular}{|c|c|c|c|}
\hline Yol & $\begin{array}{c}\text { Standardize } \\
\text { Beta Katsayısı }\end{array}$ & Standart Hata & $\begin{array}{c}\text { Anlamlılık } \\
\text { Düzeyi }\end{array}$ \\
\hline GL $\rightarrow$ BP & 0,486 & 0,047 & $<0,01$ \\
\hline
\end{tabular}

Tablo 8'de yer alan değerler incelendiğinde, girişimci liderlik ile bireysel performans değişkenleri arasındaki standardize edilmiş Beta katsayısının anlamlı 
Girişimci Liderlik Ölçeği’nin Geçerlik ve Güvenirlik Çalışması ve

Girişimci Liderliğin Bireysel Performansa Etkisi

olduğu $(\mathrm{p}<0,01)$ görülmektedir. GL ile BP değişkenleri arasındaki ilişki katsayısı 0,486'dır. Yani lojistik firmasında çalışanların girişimci liderlik özelliklerinde bir birimlik artış, bireysel performansı 0, 486 birim artırmaktadır.

\section{Sonuç ve Öneriler}

Yapılan çalışmada, ilk olarak Girişimci Liderlik Ölçeği Türkçeye uyarlanmış, müteakiben girişimci liderliğin bireysel performans üzerindeki etkisi araştırılmıştır. Araştırmanın anakütlesi Mersin'de faaliyet gösteren lojistik firmalarında çalışanlar olarak belirlenmiştir. Veriler kolayda örneklem yöntemi ile toplanmıştır. Örgütlerin başarısını önemli derecede etkileyen güncel liderlik yaklaşımlarından girişimci liderliğin bireysel performansa etkisi elde edilen veriler kullanılarak korelasyon ve yapısal eşitlik modeli yöntemleri yardımıyla açıklanmaya çalışılmıştır.

Analiz sonuçları incelendiğinde; yazarlar tarafından Türkçe geçerlik ve güvenirlik çalışması yapılan Girişimci Liderlik Ölçeği'nin Türkiye'de sosyal bilimler alanında yapılan çalışmalarda kullanılabileceği; girişimci liderliğin de bireysel performansı etkilediği tespit edilmiştir.

Girişimci liderin, birlikte çalıştığı kişileri de girişimci olarak görmesi ve onlara bu kapsamda davranması, onların özgün olmasını, yaratıcılığını ortaya çıkarmasını ve yenilikler yapmasını sağlayacaktır. Ayrıca çalışanlar girişimci liderin rol model olması ile iş kurmak için sadece paraya ihtiyaç olduğu düşüncesinden uzaklaşacak ve girişimciliği yaşayarak öğrenecektir.

$\mathrm{Bu}$ araştırmanın bazı sınırlılıkları da bulunmaktadır. Araştırmanın boylamsal olmaması, belirli bir sektörde ve belirli bir coğrafi bölgede yapılmış olması önemli bir kısıttır. Belirli aralılarla elde edilecek araştırma sonuçlarının daha açıklayıcı olabileceği değerlendirilmektedir. Müteakip araştırmalarda; Türkiye'de farklı örgütlerden sağlanan verilerin analiz edilmesi suretiyle daha geniş bir perspektif sağlanabilir.

\section{Extended Summary}

\section{Introduction}

In this study, the validity and reliability study of the "Entrepreneurial Leadership Scale" developed by Renko et al. (2015) to adapt to Turkish, was 
conducted and then it was investigated how entrepreneurial leadership behavior affects the individual performance of employees.

\section{Material and Experimental Studies}

The research participants consists of employees of logistics companies operating in Mersin and the total number of participants is 3000 people and the sample is 453 people. The data used in the study was collected with two scales and through easy sampling method. In this study, explanatory and confirmatory factor analysis were used to determine the validity and reliability of the scales, correlation analysis was used to determine the relationships between the variables and structural equation model analysis methods were used in the structural analysis of the established model. The analyses performed in the study were done with the SPSS and AMOS package programs.

\section{Results and Recommendations}

At the end of the study, it was concluded that the Entrepreneurial Leadership Scale is a one-dimensional scale, a factor explained the total variance of the model by $65.807 \%$, that the factor loads are above 0.7 and that the goodness of fit values are $\chi^{2} / \mathrm{df}: 2.758$, GFI: 0.973, CFI: 0.987, RMSEA: 0.062. In addition, it was concluded that the relationship between the variables was significant and moderate in the same direction $(r=0.445, \mathrm{p}<0.01)$ and entrepreneurial leadership significantly affected individual performance. The study is considered contribute to existing research on the organizational behavior.

\section{Kaynakça}

\section{Makaleler}

Alyılmaz, S. ve Polatcan, F. (2018). İletişim Kurma İstekliliği Ölçeği: Bir Ölçek Geliştirme Çalışması. Uluslararası Türkçe Edebiyat Kültür Eğitim Dergisi, $7(1), 447-458$.

Bagheri, A. (2017). The Impact of Entrepreneurial Leadership on Innovation Work Behavior and Opportunity Recognition in High-technology SMEs. The Journal of High Technology Management Research, 28(2), 159-166.

Becherer, R.C., Mendenhall, M. ve Eickhoff, K.F. (2008). Separated at Birth: An Inquiry on the Conceptual Independence of the Entrepreneurship and the 
Girişimci Liderlik Ölçeği’nin Geçerlik ve Güvenirlik Çalışması ve

Girişimci Liderliğin Bireysel Performansa Etkisi

Leadership Constructs. New England Journal of Entrepreneurship, 11(2), 13-27.

Beffort, N. ve Hattrup, K. (2003). Valuing Task and Contextual Performance: Experience, Job Roles, and Ratings of the Importance of Job Behaviors. Applied H.R.M. Research, 8(1), 17-32.

Brislin, Richard W. (1970). Back-translation for Cross-cultural Research, Journal of Cross-Cultural Psychology, 1(3), 185-216.

Cogliser, C.C. ve Brigham, K.H. (2004). The Intersection of Leadership and Entrepreneurship: Mutual Lessons to Be Learned. The Leadership Quarterly, 15, 771-799.

Cunningham, J.B. ve Lischeron, J. (1991). Defining Entrepreneurship. Journal of Small Business Management 29(1), 45-62.

Çalışkan, A. ve Akkoç, İ. (2012). Girişimci ve Yenilikçi Davranışın İş Performansına Etkisinde Çevresel Belirsizliğin Rolü. Çă̆ Üniversitesi Sosyal Bilimler Dergisi, 9(1), 1-29.

Esmer, Y. ve Dayl, F. (2017). Entrepreneurial Leadership: A Theoretical Framework. Mehmet Akif Ersoy Üniversitesi İktisadi ve İdari Bilimler Fakültesi Dergisi, 4(2), 112-124.

Fernald Jr., L.W., Solomon, G.T. ve Tarabishy, A. (2005). A New Paradigm: Enrepreneurial Leadership. Southern Business Review, 30(2), 1-10.

Fontana, A. ve Musa, S. (2017). The Impact of Entrepreneurial Leadership on Innovation Management and its Measurement Validation. International Journal of Innovation Science, 9(1), 2-19.

George, J.M. ve Brief, A.P. (1992). Feeling Good-doing Good: A conceptual Analysis of the Mood at Work-Organizational Spontaneity Relationship. Psychological Bulletin 112, 310-329.

Gilbao, S. ve Shirom, A.A. (2008). A Meta-analysis of Work Demand Stressors and Job Performance: Examining Main and Moderating Effects. Personnel Psychology, 61, 227-271. 
Gupta, V., MacMillan, I.C. ve Surie, G. (2004). Entrepreneurial Leadership: Developing and Measuring a Cross-cultural Construct. Journal of Business Venturing, 19(2), 241-260.

Güngören, C.Ö., Bektaş, M., Öztürk, E. ve Horzum, M.B. (2014). Tablet Bilgisayar Kabul Ölçeği - Geçerlik ve Güvenirlik Çalışması. Eğitim Bilim, 39(176), 69-79.

Jagdale, D. ve Bhola, S.S. (2014). Entrepreneurial Leadership and Organizational Performance with Reference to Rural Small Dcale Engineering Industry in Pune Distinct. International Multidisciplinary Research Journal Golden Research Thoughts, 4(2), 1-9.

Karol, R. (2015). Leadership in the Context of Corporate Entrepreneurship. Journal of Leadership Studies, 8(4), 30-34.

Kidwetl, R.E. ve Bennett, N. (1993). Employee Propensity to withold Effort: A Conceptual Model to Intersect Three Avenues of Research. Academy of Management Review, 18, 429-456.

Mgeni, T.O. (2015). Impact of Entrepreneurial Leadership Style on Business Performance of SMEs in Tanzania. Entrepreneurship \& Organization Management, 4(2), 1-9.

Motowidlo, S.J. ve Van Scotter, J.R. (1994). Evidence that Task Performance Should be Distinguished from Contextual Performance. Journal of Applied Psychology, 79, 475-480.

Rahim, H.L., Abidin, Z.Z., Mohtar, S. ve Ramli, A. (2015). The Effect of Entrepreneurial Leadership towards Organizational Performance. International Academic Research Journal of Business and Technology, 1(2), 193-200.

Renko, M., Tarabisby, A.E., Casrud, A.L. ve Brannback, M. (2015). Understanding and Measuring Entrepreneurial Leadership Style, Journal of Small Business Management, 53(1), 54-74.

Sacket, P.R. ve Wanek, J.E. (1996). New Developments in the Use of Measures of Honesty, Integrity, Conscientiousness, Dependability, Trustworthiness and Reliability for Personnel Selection. Personnel Psychology, 49, 787-830. 
Girişimci Liderlik Ölçeği’nin Geçerlik ve Güvenirlik Çalışması ve

Girişimci Liderliğin Bireysel Performansa Etkisi

Saygın, M. ve Bekmezci, M. (2019). Mersin İlinde Öğrenim Gören Üniversite Öğrencilerinin Girişimcilik Eğilimleri: Devlet ve Vakıf Üniversitesi Karşılaştırması. Toros Üniversitesi İ̈BF Sosyal Bilimler Dergisi, 6(11), 108123.

Shane, S. ve Venkataraman, S. (2000). The Promise of Entrepreneurship as a Field of Research. Academy of Management Review, 25, 217-226.

Smith, C.A., Organ, D.W. ve Near, J.P. (1983). Organizatonal Citizenship Behavior: Its Nature and Antecedents. Journal of Applied Psychology, 68, 655-663.

Tarabishy, A., Solomon, G., Fernald, L.W. ve Sashkin, M. (2005). The Entrepreneurial Leader's Impact on the Organization's Performance in Dynamic Markets. The Journal of Private Equity, Fall, 20-29.

Yaşlığlu, M. M. (2017). Sosyal Bilimlerde Faktör Analizi ve Geçerlik: Keşfedici ve Doğrulayıcı Faktör Analizlerinin Kullanılması. İstanbul Üniversitesi İsletme Fakültesi Dergisi, Özel Sayı, (46), 74-85.

Zorlu, K. ve Tetik, F. (2018). Girişimci Liderlik Davranışının Çalışan Yaratıcılığına Etkisi. Selçuk Üniversitesi Sosyal Bilimler Enstitüsü Dergisi, 39, 297-307.

\section{Kitaplar}

Akdoğan, A.A. (2019). Girişimciliğin Önemi ve Başarılı Girişimcilik için Dikkat Edilmesi Gereken Hususlar. İçinde Saygın, M. (Ed.) İşletmelere ve Girişimciliğe Güncel Bakış. Eğitim, Konya, 19-23.

Barutçugil, İ. (2002). Performans Yönetimi. Kariyer, İstanbul.

Bekmezci, M. (2020). Balanced Scorecard (Dengeli Ölçüm Kartı): Stratejik Performans Ölçümü Bakış Açısıyla. Altınordu, Ankara.

Campbell, J.P. (1990). Modeling the Performance Prediction in Industrial and Organizational Psychology. İçinde Dunnette, M., Hough, L.M. (Eds.). Handbook of Industrial and Organizational Psychology, 1, 2nd Ed., Consulting Psychologists Press, Palo Alto, 687-731.

Civelek, M.E. (2018). Yapısal Eşitlik Modellemesi Metodolojisi. Beta, İstanbul. 
Clark, J.P. ve Hollinger, R.C. (1983). Theft by Employeesin Work Organizations: Executive Summary. National Institute of Justice, Washington DC.

Çalık, T. (2003). Performans Yönetimi. Gündüz Eğitim ve Yayıncılık, Ankara.

Erbaşlar, G. (2017). Girişimcilik. Nobel, Ankara.

Güney, S. (2015). Liderlik, Nobel, Ankara.

Hisrich, R. ve Peters, M.P. (2002). Entrepreneurship, McGraw Hill, USA.

Kane, J.S. (1986). Performance Distribution Assessment. İçinde Berk, R.A. (Ed.). Performance Assessment. Johns Hopkins University Press, Baltimore, 237273.

Köksal, M. (2005). İsletmelerde Performans Değerlendirme. Avcı Ofset, İstanbul.

Mucuk, İ. (2000). Modern İşletmecilik, Türkmen, İstanbul.

Murphy, K.R. (1989). Dimensions of Job Performance. İçinde Dillion, R., Pelligrino, J. (Eds.). Testing: Applied and Theoretical Perspectives. Praegner, New York, 218-247.

Özdamar, K. (2017). Ölçek ve Test Geliştirme Yapısal Eşitlik Modellemesi IBM SPSS, IBM SPSS AMOS ve MINITAB Uygulamalı. Nisan Kitabevi, Eskişehir.

Pallant, J. (2017). SPSS Kullanma Klavuzu SPSS ile Adım Adım Veri Analizi. (Çev. Sibel Balcı, Berat Ahi). Anı Yayınc1lı, Ankara.

Renko, M. (2017). Entrepreneurial Leadership. Forthcoming in "Nature of Leadership", 3rd edition. Edited by David V. Day and John Antonakis. SAGE Publications. https://ssrn.com/abstract=2977744 (Erişim tarihi: 25.07.2019).

Sekaran, U. (1992). Research Methods for Business. John Wiley ve Sons Inc., Canada.

Şeşen, H. ve Burmaoğlu, S. (2012). Girişimci Liderlik. İçinde Tabak, A., Şeşen, H. ve Türköz, $T$ (Eds.). Liderlikte Güncel Yaklaşımlar. Detay Yayıncılık, Ankara. 
Girişimci Liderlik Ölçeği’nin Geçerlik ve Güvenirlik Çalışması ve

Girişimci Liderliğin Bireysel Performansa Etkisi

Tabachnick, B.G. ve Fidell, L.S. (2001). Using Multivariate Statistic (4th. Ed.), Needman Heights. MA: Ally\&Bacon.

Uygun, R.K. (2018). Girişimci Türleri ve Örnek Alan Çalışmaları. Ekin, Ankara.

Ürper, Y. (2015). Girişimcilik Kavramı, Çeşitleri ve Girişimcilikte Etik. İçinde Ürper, Y. (Ed.). Girişimcilik ve İş Kurma, Anadolu Üniversitesi Yayınları, Eskişehir, 2-21.

Ülgen Aydınlık, A. (2017). Girişimcilik. Beta, İstanbul.

Van Dyne, L. Cummings L.L. ve Parks, J.M. (1995). Extra-role Behaviors: Its pursuit of Construct and Definitional Clarity (A Bridge over Muddied Waters). İçinde Cummings, L.L. ve Staw, B.M. (Eds.). Research in Organizational Behavior (17, 215-285). CT: JAI Press, Greenwich.

Viswesvaran, C. (2009). Bireysel İş Performansı Değerlendirmesi: Geçen Yüzyılın Incelenmesi ve Geleceğe Bir Bakış. İçinde Anderson, N., Öneş, D.S., Sinangil, H.K. ve Viswesvaran, C. (Eds.), Çev. Koordinatörü: Bahar Öz, Literatür, İstanbul, 137-156.

Y1lmaz, H. (2011). Güçlendirici Liderlik. Beta, İstanbul.

Welbourne, T.M., Johnson, D.E. ve Erez, A. (1997). The Role-based Performance Scale: Validity Analysis of a Theory-based Measure. Cornell University ILR School Center for Advanced Human Resource Studies Working Paper Series, Working Paper 97-05, 1-30.

\section{Tezler}

Yelboğa, A. (2003). İnsan Kaynakları Yönetiminde Performans Değerlendirilmesi için Geliştirilen Bir Ölçeğin Psikometrik Özelliklerinin İncelenmesi, Yayımlanmamış Yüksek Lisans Tezi, Ankara Üniversitesi Eğitim Bilimleri Enstitüsü, Ankara.

\section{Web Sayfaları}

http://www.mhprofessional.com/downloads/products/0072262354/0072262354_ appendix_C.pdf adresinden 03.08.2019 tarihinde alınmıştır. 


\section{Girişimci Liderlik Ölçeği'nin Orijinali}

In the following set of questions, think of your immediate manager (or team leader). How well do the following statements describe him/her? (If you have many immediate managers, please pick one).

1. Often comes up with radical improvement ideas for the products/services we are selling

2. Often comes up with ideas of completely new products/services that we could sell.

3. I Takes risks.

4. Has creative solutions to problems.

5. Demonstrates passion for his/her work.

6. Has a vision of the future of our business.

7. Challenges and pushes me to act in a more innovative way.

8. Wants me to challenge the current ways we do business.

\section{Ölçeğin Türkçe Uyarlaması}

Aşağıdaki ifadeler size en yakın yöneticinizi ne kadar iyi tanımlar? Eğer size yakın birden fazla yöneticiniz varsa, lütfen birini seçerek, soruları onu düşünerek cevaplayınız.

1. Çoğu zaman sattığımız ürün/hizmet için radikal iyileştirme fikirleri ileri sürer.

2. Çoğu zaman satabileceğimiz, tamamen yeni ürün/hizmet, fikirleri vardır.

3. Risk alır.

4. Sorunlara yaratıcı çözümler bulur.

5. İşine tutkulu olduğunu gösterir.

6. İşimizin geleceği hakkında bir vizyona sahiptir.

7. Beni zorlar, daha yenilikçi davranmam konusunda teşvik eder.

8. İşin mevcut yapılış şekline meydan okumamı ister. 